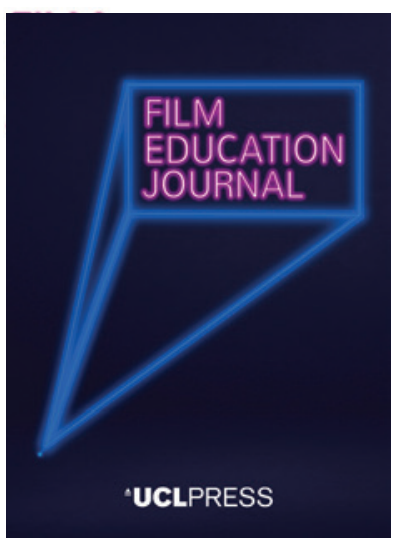

UCLPRESS

FILM EDUCATION JOURNAL

ISSN 2515-7086 (Online)

Journal homepage:

https://www.uclpress.co.uk/pages/film-education-journal

\title{
Immaterial cultural heritage and a sense of place in film-based art education: A case study of a documentary film project with secondary school children as part of Cine en curso Chile
}

Felipe Correa iD

\section{How to cite this article}

Correa, F. (2020) 'Immaterial cultural heritage and a sense of place in film-based art education: A case study of a documentary film project with secondary school children as part of Cine en curso Chile'. Film Education Journal, 3 (2), 123-37. Online. https:// doi.org/10.14324/FEJ.03.2.02

Submission date: 11 March 2020

Acceptance date: 12 May 2020

Publication date: 26 November 2020

\section{Peer review}

This article has been peer-reviewed through the journal's standard double-blind peer review, where both the reviewers and authors are anonymized during review.

\section{Copyright}

(C) 2020 Correa. This is an open-access article distributed under the terms of the Creative Commons Attribution Licence (CC BY) 4.0 https://creativecommons.org/licenses/by/4.0/, which permits unrestricted use, distribution and reproduction in any medium, provided the original author and source are credited.

\section{Open access}

The Film Education Journal is a peer-reviewed open-access journal. 


\title{
Immaterial cultural heritage and a sense of place in film-based art education: A case study of a documentary film project with secondary school children as part of Cine en curso Chile
}

\author{
Felipe Correa* - Gaticine - Centro de desarrollo social del cine, Santiago, \\ Chile
}

\begin{abstract}
The following article describes the process of a documentary filmmaking programme at a secondary school in Chile, which encourages students to engage with a sense of place and intangible cultural heritage. Run by Gaticine - Centro de desarrollo social del cine (Centre for the Social Development of Cinema) in partnership with $\mathrm{A}$ Bao A Qu, a non-profit organization based in Barcelona, the programme assists students in discovering and analysing documentary films from different times and cultures over the course of a year, while performing practical filmmaking inside and outside the school. At the end, a short film project is developed that is premiered in a local cinema. This essay provides a brief overview of the principles and methodology of the Cinema en curs programme, before offering a socio-educational consideration of the school in which it was developed and, finally, an analysis of the project's delivery.
\end{abstract}

Keywords: documentary cinema, art education, sense of place, immaterial cultural heritage, project-based learning, place-based art education, Cinema en curs, Cine en curso Chile, film education

\section{Introduction}

In Chile, several initiatives related to film education have recently been developed within school contexts, among them the Cineteca Nacional's Escuela al cine (School to Cinema) and Cero en conducta (Zero in Conduct). In Gaticine - Centro de desarrollo social del cine (Centre for the Social Development of Cinema), we have been working since 2014 to promote the transmission of cinema as an artistic experience within schools. As part of ongoing work exploring ways in which film might be taught in schools, Gaticine frequently works with other organizations to develop programmes such as Cine en curso Chile.

Cine en curso Chile is part of the wider Cinema en curs project, an international film pedagogy initiative created in 2005 by $\mathrm{A}$ Bao A Qu, a cultural organization from Barcelona. Cinema en curs focuses on the transmission of cinema at school, as art and creation. As A Bao A Qu's founders Núria Aidelman and Laia Colell (2014: 25) describe, Cinema en curs 'is conceived from the desire and the need to encourage children and young people to discover, in a profound and active way, cinema as an art and as a creative process. A kind of cinema which they wouldn't have any access to or to which they might never know anything about (as many adults also don't know) if it is not introduced in school.' 
Cinema en curs's methodology is based on the interlinked relationship between watching and making films, arising from the understanding that the same type and level of attention and openness are used to watch films as to make them. It is therefore Cinema en curs's conviction that when engaging in the creative process of both watching and making films students find themselves in a place of dialogue with filmmakers.

Another fundamental motivation within Cinema en curs is that the experience of cinema serves as a means of exploring the places and wider environments in which participants live, providing students with a way to share their discoveries through cinema. Alongside these cinematic explorations of place, Cinema en curs also foregrounds the role of filmmaking as a means of documenting, celebrating and preserving traditional trades and crafts within a local area: trades that are carried out in contexts that frequently prove to be cinematically interesting and which incorporate processes new to students, which they are able reveal through film. One of the related expectations of the project in this respect is that students will be able to engage with and build relationships with skilled craftspeople, who are then able to show the commitment with which crafts are approached and the fulfilment received in return. Here, an understanding of creative work is proposed by Cinema en curs to allow students to experience a moment that transcends daily life. Cinema en curs thus pursues a form of learning that simultaneously is about cinema and takes place through cinema.

Cinema en curs has been implemented internationally in both primary and secondary settings and takes place throughout the school year within the school day (rather than in the extra-curricular setting of an after-school club), and it is delivered by a two-person partnership of a class teacher and filmmaker. The programme is introduced within a given subject (language, history, philosophy, arts, etc.), and looks to find ways in which it can complement and articulate the host subject's learning aims and outcomes. As part of their experience of Cinema en curs, students participate in a series of pedagogically focused excursions of the area surrounding the school, in order to further connect them with the places and community settings in which they live, and - moreover - to share their experiences, reflections and learning about cinema with others.

Finally, a further aspect of Cinema en curs, which we have specifically sought to emphasize in Cine en curso Chile, is the sociocultural dialogue that can be enabled within the framework of a diverse cohort of participating groups. Each school brings aspects of its own identity in filmmaking work, and this later allows an interesting dialogue between students in screenings where these experiences are shared and the works are exhibited. This aspect of the project is particularly interesting within a Chilean setting, given the marked aspects of segregation that exist within the national education sector.

This article considers Gaticine's work with Cine en curso Chile in Alicura, a small, mixed primary/secondary school in Santiago with a specialist focus on reintegrating 'at risk' children back into the school system. First, I offer a description and characterization of the educational context in which the project was executed, considering in particular some of the key conditions that shaped and determined its development. Following this, I consider the delivery of the programme over the course of a school year, while analysing some of the key aspects, such as: an approach to art that is based upon the everyday experiences of children; the project goal of helping students make connections between cinema and their own realities from a creation perspective and through the making of a short film; and the ways in which cinema can serve as a means of accessing other realities beyond that of the students' daily life. 
Finally, I argue in conclusion that although the students' initial aims were to watch and produce entertaining films, their engagement with the work of other filmmakers and their own documentary filmmaking process seemed to foster a sense of filmmaking as both an art and a craft, while also helping them to see their surroundings in a different light.

\section{Cine en curso Chile at Alicura School}

Alicura is a small school of 108 students (15 per class) in Peñalolén, in the Santiago province of Chile. Founded relatively recently, in 2011, the school focuses on reintegration programmes for children and young people with learning disabilities, promoting continuity within the educational system. According to a study of Chilean programmes in educational reintegration (Corte and Concha, 2016), most of these children and young people have suffered severe violations of their rights in different aspects of their life. The school tends to work in particular with young people who have left the school system or who have to repeat two or more years of their studies. Alicura offers a 'levelled' approach to study whereby two school years are condensed into one. According to the school's Institutional Educational Project (Colegio Alicura, 2018), one of Alicura's key strategic aims is to implement a school culture that fosters a sense of continuity across school life.

Arising from the interest in artistic development mentioned in the school's institutional mission, which describes the aim of seeking to 'enhance the emotional, artistic and intellectual development of all our students, based on the development of meaningful learning, good treatment and equal opportunities' (Colegio Alicura, 2018), Alicura School saw in Cine en curso Chile an opportunity for its students to have a creative experience and sensitively engage with their surrounding environment. As has been explored elsewhere in Elliot Eisner's (2018) discussion of art education, Cinema en curs is motivated by the conviction that art, as an act of observing intensely and thus of developing sensitivities to the world around us, can produce qualitative rewards in terms of how life is experienced on a day-to-day basis.

One of the central foundations of Cine en curso Chile's approach - as regards the specific framework of film education - is the work of Alain Bergala (2016). Cine en curso Chile draws in particular upon three key aspects of Bergala's work: the notion of art as a source of alterity within a school context (Bergala, 2016: 39), the inseparable relationship between watching and making cinema through creative analysis (ibid.: 74) and Bergala's understanding of the steps towards creative practice (ibid.: 95).

Further starting points for Cine en Curso Chile's methodology can be found more generally in approaches to place-based art education (Blandy and Hoffman, 1993), which employ art as a means of helping students make connections with social, cultural and environmental issues, fostering their agency and abilities to be critical subjects and raising their awareness of community.

Cine en curso Chile began its activities at Alicura in March 2014, engaging with students every two weeks. The project was led by myself (Felipe Correa), filmmaker and director of Gaticine - Centro de desarrollo social del cine, and Marcela Zegarra, a primary teacher at Alicura. The group consisted of 15 students -13 boys and 2 girls aged between 11 and 16, corresponding to Alicura's 3rd level of study. Throughout the year, session by session, students carried out practical work in dialogue with the films they were watching, culminating in the production of a final short film.

During the first semester, we organized an introduction to cinema, which focused respectively upon two practical exercises: 'Empty Spaces' (www.fotografiaencurs.org/ 
es/node/38) and 'Experimental Shots'. For 'Empty Spaces' the students observed the school grounds, through which they travelled daily, with a new attentiveness to colours, light and perspective (see Figures 1 and 2). Their viewpoint was aided by an analysis they had previously undertaken of images by photographers such as Humberto Rivas and Carlos Cánovas. Students were tasked with conveying a feeling of emptiness within a photograph they took themselves using a school camera, with careful consideration as to framing and composition. The photographs were then reviewed in class, with students encouraged to participate in discussion and critical analysis, based upon the criteria given for the photograph's realization. This first part of the project concluded with an open exhibition (within Alicura, which the entire school community was invited to attend) of printed photographs in the 'Cinema Space', a place within the classroom where we organized and displayed all the images, texts, film titles and material worked on throughout the project.

This first exercise allowed students to begin exploring and observing everyday life in a different way. As such, 'Empty Spaces' embodied one of the first moments in which students were encouraged to engage with their environment, requiring them to sharpen their senses and resignify aspects of their own realities from an aesthetic perspective. Students were allowed to take only three photographs, so had to think deeply about the expressive choices used. The subsequent exhibition featured places known to everyone at Alicura (such as exercise machines or the school playground), now presented via a different sense of perspective and intention; rendering feelings of emptiness through visual parameters such as contrast, lights and shadows, lines, colours, composition.

Approaching photography in this detailed manner required us to encourage students to overcome an initial sense of impatience, and to face difficulties engaging with the analysis of the photographers we attempted to review as a class. Initially, students seemed to find it difficult, and at times impossible, to stop and fully

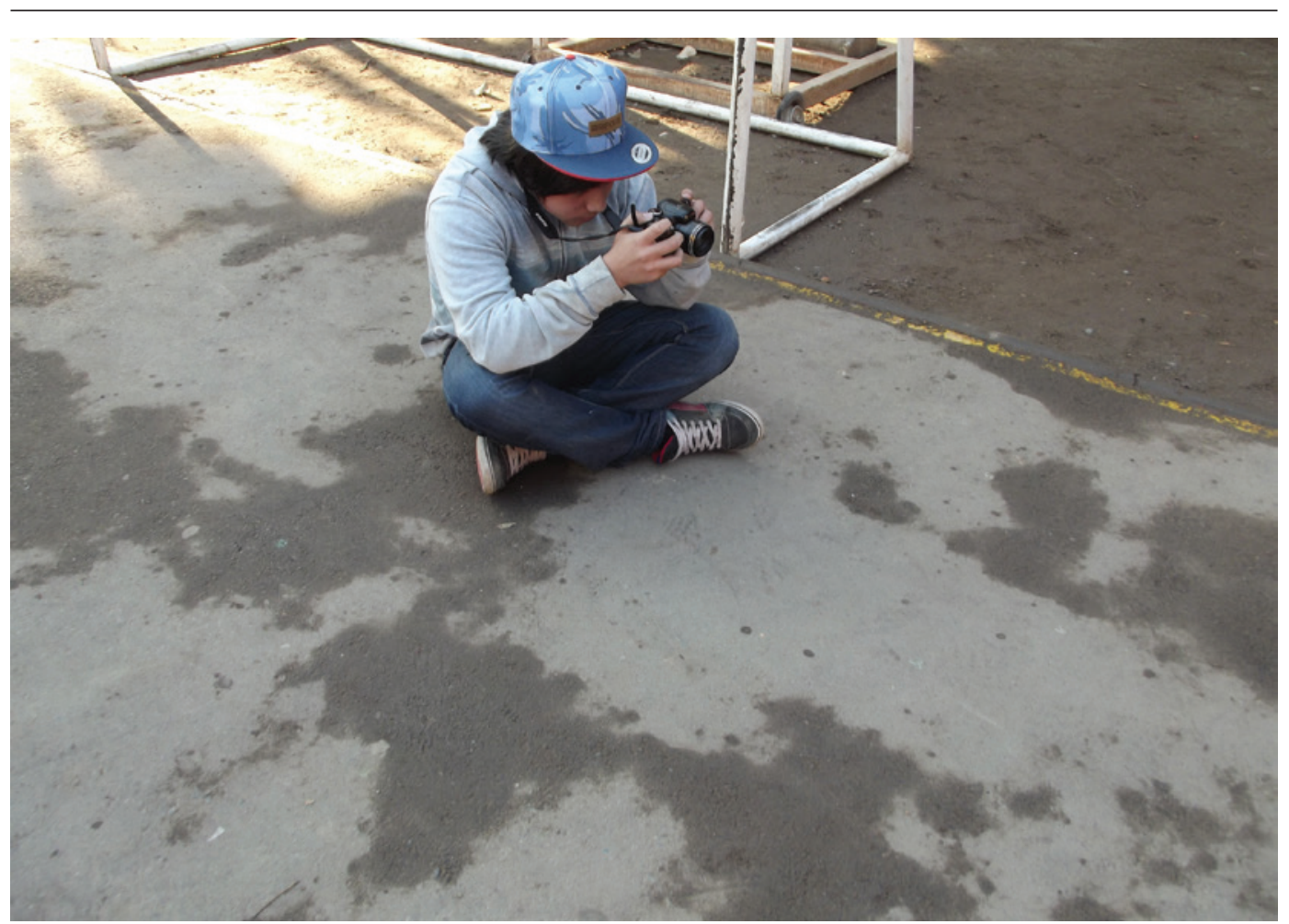

Figure 1: Photographing at school 


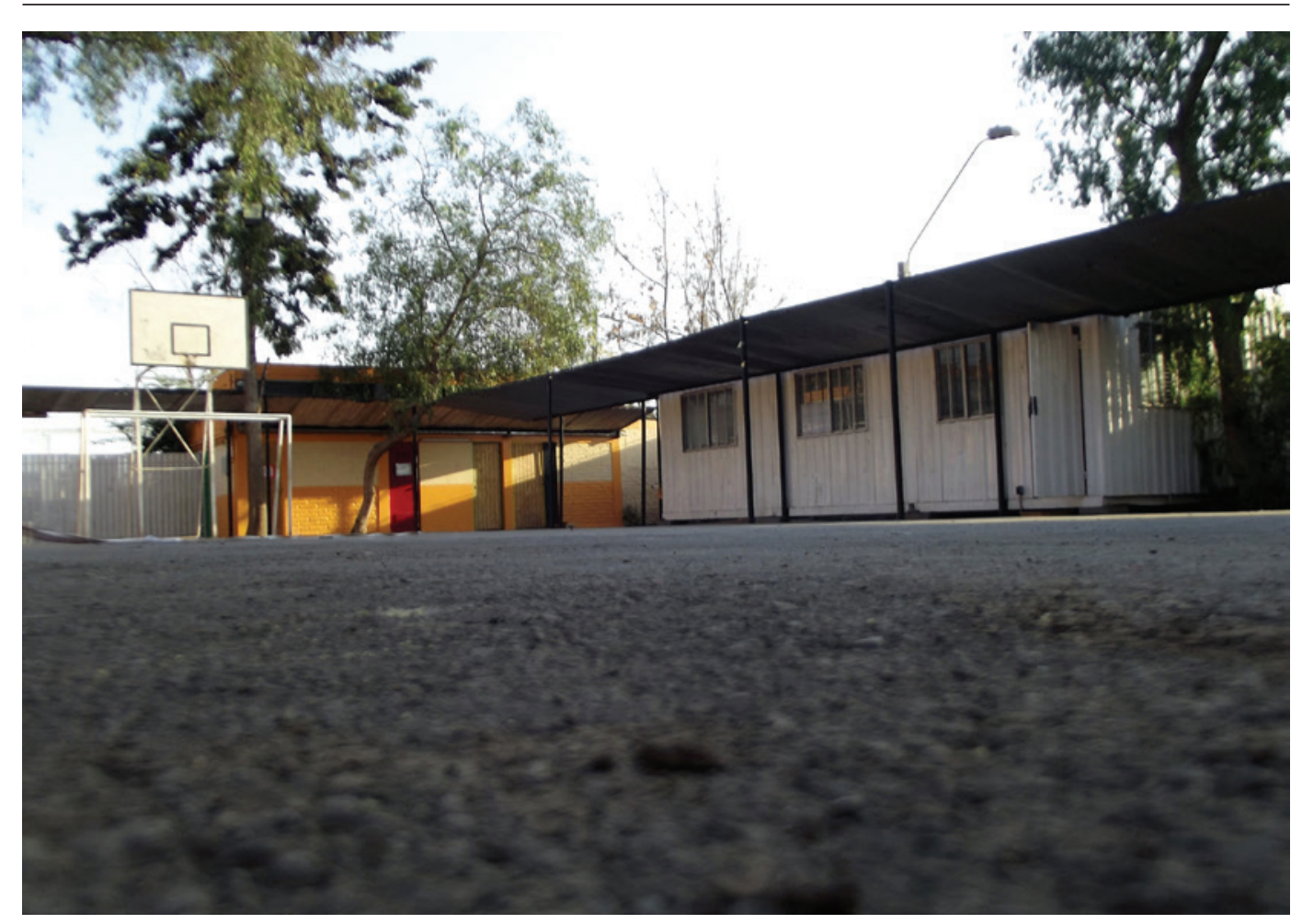

Figure 2: Choosing an empty space

observe the photographs, sharpen their gaze, analyse the details and openly share their thoughts and feelings about an image. Frequently we found students were strongly critical of the activities we were proposing, which then sometimes gave way to indifference. We found, however, that this situation began to change when we moved onto practical work. The photographic choices we had initially reviewed in class were resignified through the creation of the students' own photographs; as the filmmaker, I gently questioned the students' decision-making process, and helped them reflect upon and be aware of the different possibilities offered within the places and moments in which they were working. I argue here that in a project of this sort it seems necessary that educators be able to resist the initial scepticism and critical attitudes of students, to play an active role in expanding students' horizon of possibilities during on-the-ground practical work. After attending the exhibition, the school principal commented that the students participating in the programme already seemed to have undergone a transformation in their views, and that they were now starting to appreciate aspects of everyday beauty that other classmates were unable to see.

The next practical exercise, 'Experimental Shots', involved the introduction of professional camera and sound equipment. Students were first taught about the use and care of this equipment, and about the collaborative teamwork (in terms of design, planning and filming) required to achieve a single shot. In order to choose what they would film themselves in their own practical work, students were asked to choose a place and activity that would identify them as a group and as a school. This group decision was made through a consensus, based on the arguments and opinions of the whole class. These discussions were informed by films reviewed with the class, such as Alain Cavalier's short documentary portrait of a middle-aged mattress maker La Matelassière (1989) or José Luis Guerín's documentary about the construction of an apartment block En Construcción (2001), where discussion focused in particular on 
certain closed shots and elements placed between the camera and the characters. Ultimately the group concluded that the shot representing their group identity would be in a sector of the schoolyard and that the action would be a game of table tennis (see Figures 3 and 4). With this work, the semester ended.

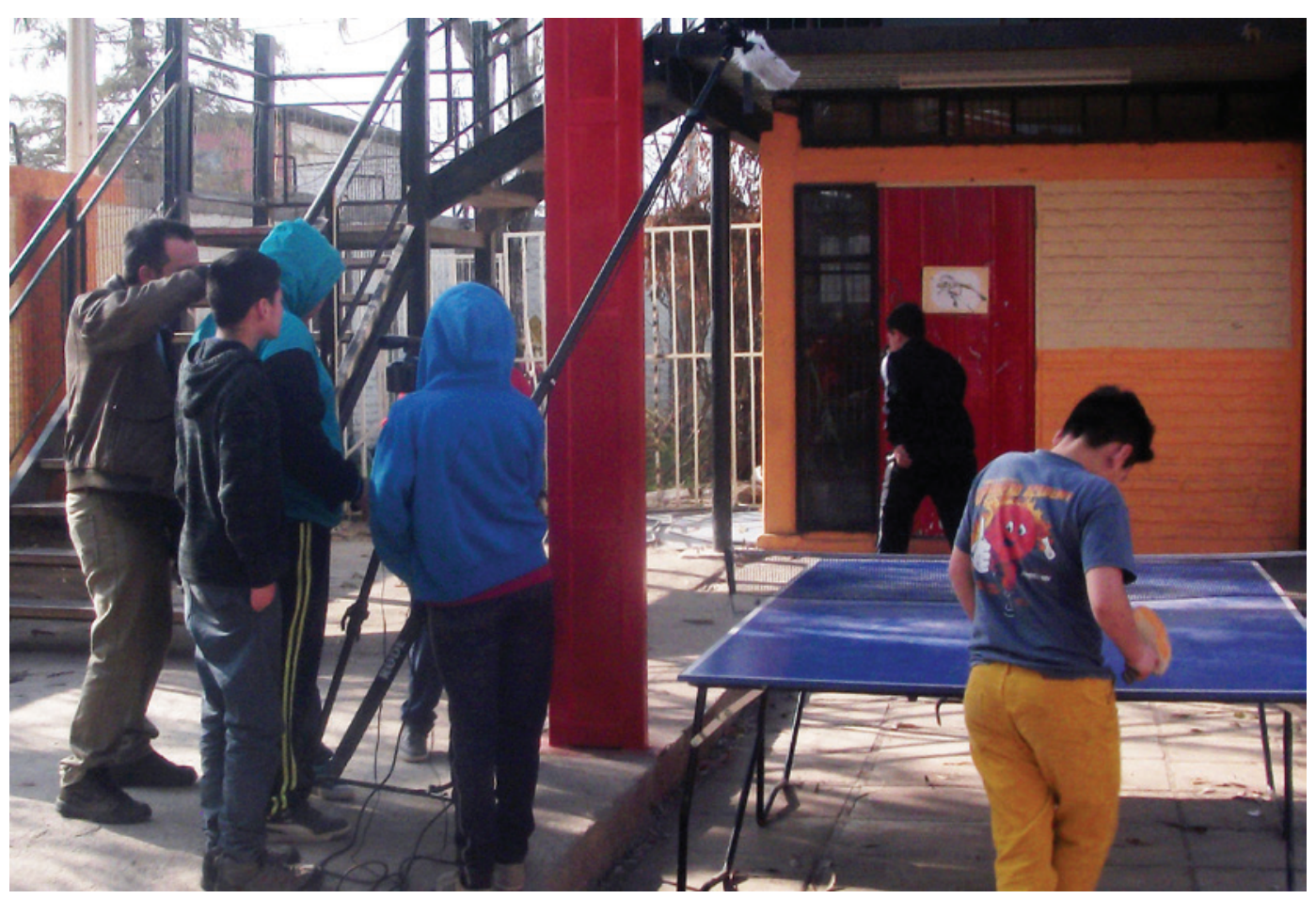

Figure 3: Introduction of filming equipment: Camera, tripod and sound

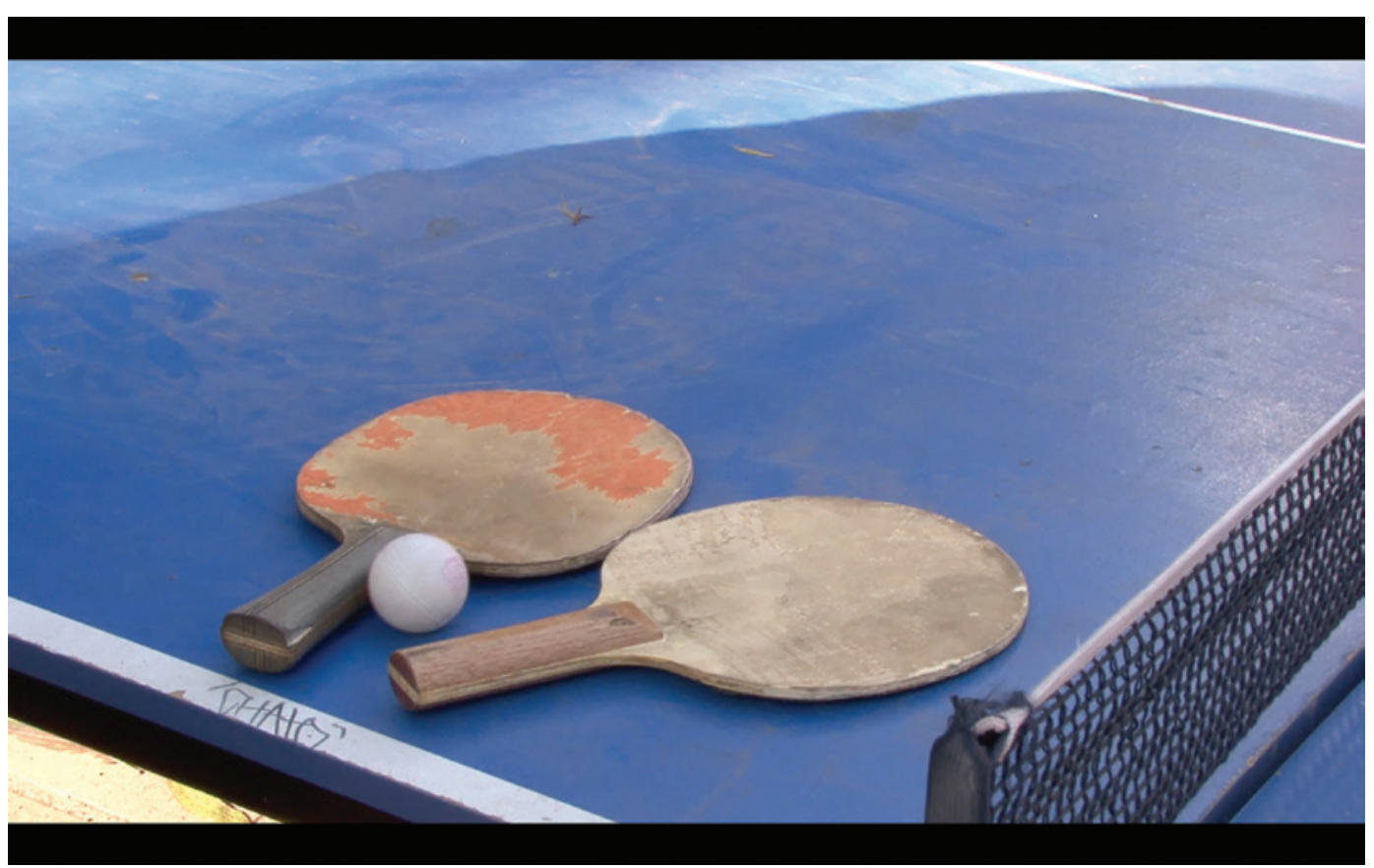

Figure 4: Still frame of an experimental shot taken shortly after introduction of the filming equipment 
During this 'Experimental Shots' exercise a question was raised by the students about the identity of the group, setting in motion a reflection upon their sense of freedom and the importance of games in their personal development. The group recognized the importance of the place where they played table tennis and the shared process of valorization the game embodied. Like the photographs reviewed at the beginning of the course, the fragments of the films analysed did not initially arouse interest among the students, who at first felt they were 'meaningless'. They wanted to keep watching the film to find out what was going on, or to watch a film with action scenes. This introduction of fragments taken from forms of cinema to which they were not accustomed seemed to create a sense of strangeness, while opening up the potential for scepticism, harsh criticism and a tendency to dismiss. Such sceptical perspectives also led to students making comparisons with what they felt was more 'normal', thus risking imposing significant limitations on the learning that could take place within the project. Once again, however, we fortunately found that, as the students became more involved and confident with the dynamics of creative analysis of documentaries and were subsequently able to contextualize their experiences of watching within that of making their own work, the films we referenced together as a class seemed to grow in significance and importance for them.

As in all the activities carried out within the programme, all students within the class were encouraged to participate: to express their own perspectives and opinions (what they saw, heard, felt and thought) and to take at least one shot themselves in order to gain the experience of an act of creation. Across the year, recognizable improvements in student self-esteem and self-confidence were observed. Chilean film educator Alicia Vega (2018) has described how art can help children gain higher levels of experience. She observed the progress children participating in her workshops had made in terms of their concentration, dedication and effort; they worked with patience and rigour and treated each other with respect and equality.

For the next stage of their work with Cine en curso Chile, students were tasked with a collective project: making a documentary short film. The production was divided into four stages: research, script, filming and editing. The theme of the documentary was to be chosen by the entire group, but with a central restriction: the film was to document and celebrate a traditional trade that could be considered as a comuna's (commune or district: the smallest administrative subdivision in Chile) intangible cultural heritage (Unesco, 2018).

Through the film's production, our intention was that the topics explored throughout the first stage of the year would deepen, within a pedagogical methodology (Mergendoller and Thomas, 2005) based on: (1) the acquisition of knowledge and skills through research, practice and creation; (2) the logical structuring of all project components; (3) decision-making in a participatory manner; and (4) the evaluation not only of the final result, but also of the process, as well as of certain key competencies such as critical thinking, collaboration, communication and creativity. Students were asked to think about themes for their documentary, to bring ideas from their lives outside school, and to ask their relatives, neighbours and friends for suggestions. Alongside these personal explorations we used the book Peñalolén Cultural Artistic Memory as a source from which to extract ideas. After much further discussion among the group, two subjects were selected: Arpilleras de Lo Hermida (a women-led organization of craftspeople who weave scenes from everyday life in burlap) and Julio González, a local craftsman making medieval armour (see Figures 5 and 6).

Two smaller groups were organized within the class, each tasked with documenting (photographing) and researching one of the chosen topics. Roles 
were allocated (presenter, photographer, interviewer and transcriber), interviews were prepared, and we discussed together some of the cinematographic criteria students should keep in mind (in terms of the characteristics of the space they would be filming in, as well as featured tools and materials, and the associations that could be drawn between these and the person being filmed) and the type of images that they had to take (interior and exterior shots, natural light, portraits, cut-ins of hands and so forth).

Before beginning, our students hung a map of the comuna in the 'Cinema Space', on the wall at the back of the classroom where, in addition to marking the places where their research would take place, the location of students' houses was also established, alongside other locations important to the students. Each group then conducted a field visit and generated material for a photographic and written presentation, in order to share it with the other classmates and ultimately to then decide together the subject of the class's short documentary. Back in the classroom, the students exhibited their respective portraits of María Madariaga (representative of the organization Arpilleras de Lo Hermida) and Julio González. In the following discussion as to which would ultimately provide the subject for the class's documentary, the bond the students felt they had generated with the subject, the place and the person they had started to portray was considered central. Here, we advised students they needed to feel a desire to know and research more about what they knew at the first outing in order to commit to making a full film about the topic they chose. From these discussions it became apparent the students felt very close to Julio González, due to both his serious and kind manner and the difficult childhood he had experienced. The interview the students conducted, lasting about three hours, allowed them to start to become acquainted with details of Julio's trade, unique in Latin America. The students were particularly struck by the level of personal commitment Julio had to his work and were attracted to his workshop, Medieval Armory Lobo (and the tools and armour he had on display there), located inside the Patio La Rosa, an open space where restaurants, dance academies and other workshops are located.

The second group's interview with María Madariaga explored the historical, social and political role of the organization Arpilleras de Lo Hermida during the period of Pinochet's dictatorship in Chile, and the way in which the organization had developed their trade throughout. Here, the students regretted not being able to visit the organization's workshop.

At this point in the programme, students have been able to explore their local area in a different way. Positioning themselves in different areas of their district, locating their experiences on a map and within the two field outings, the students were able to share with each other new experiences of their local environment. In their respective visits to local craftspeople, we observed a remarkable sense of agency regarding the roles each student played when conducting their interviews, each performing their own task carefully and responsibly.

The group were unanimous in choosing Julio González to be the subject of their documentary. Julio agreed and seemed grateful to have been selected. The next stage of the project was to gain a reflective perspective of the work process of the craftsman. A simplified script or global conception chart (a schematic table depicting an overview of the scenes and references for a prospective film project) was developed, which followed the different stages of manufacturing of a piece of armour. Each stage would be a block or sequence, which a team of students would have to shoot on a certain date. The class was divided into three teams, each one consisting 


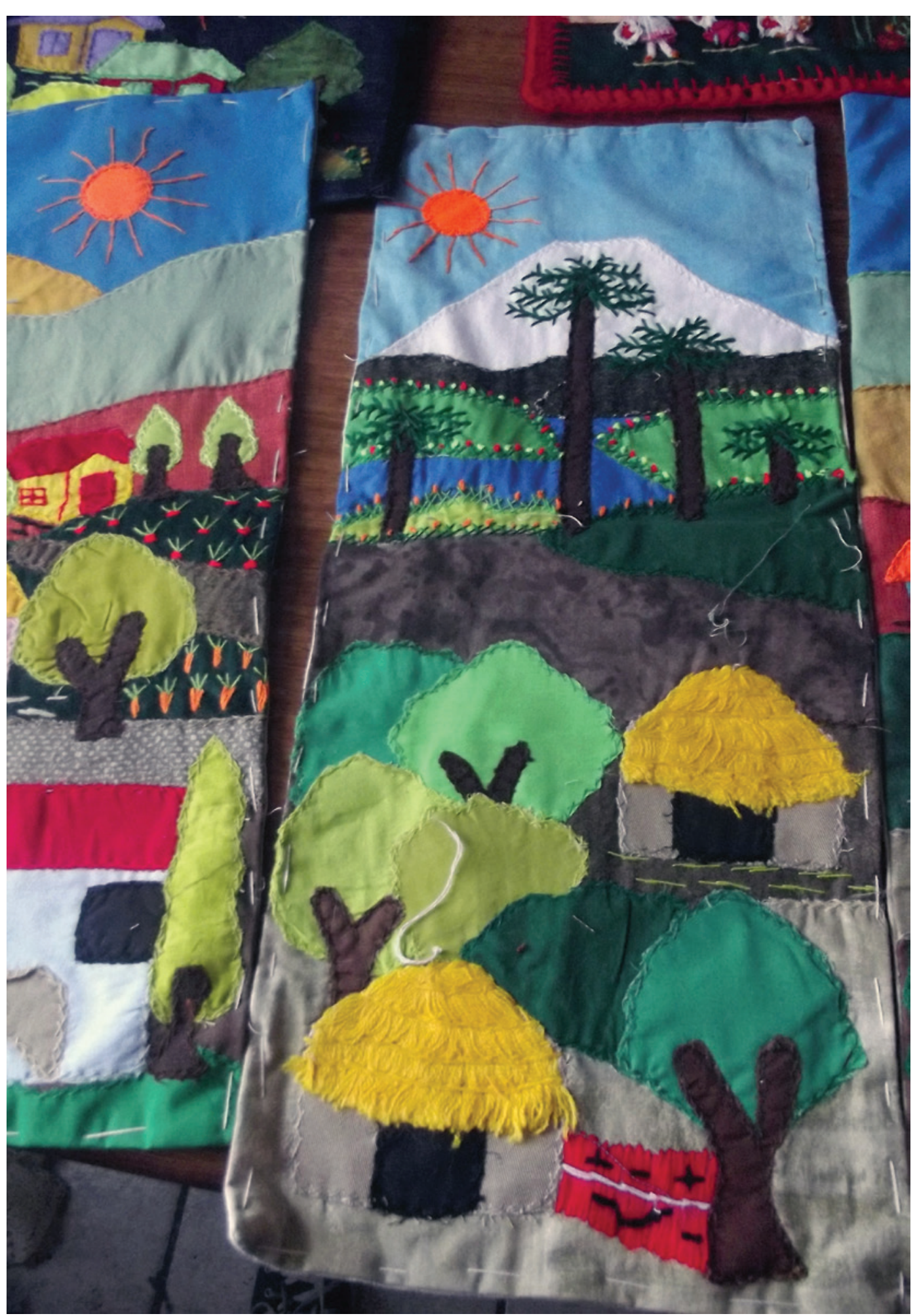

Figure 5: Output research and documentation: María Madariaga (Arpilleras de Lo Hermida)

of a director, cameraperson, soundperson, director's assistant and clapperboard. In developing this script the fragments of films that had been analysed in previous classes were also used as guides. Johan Van der Keuken's De platte jungle (The Flat Jungle, 1979) was referenced in terms of how the characters would be portrayed, Vittorio de 


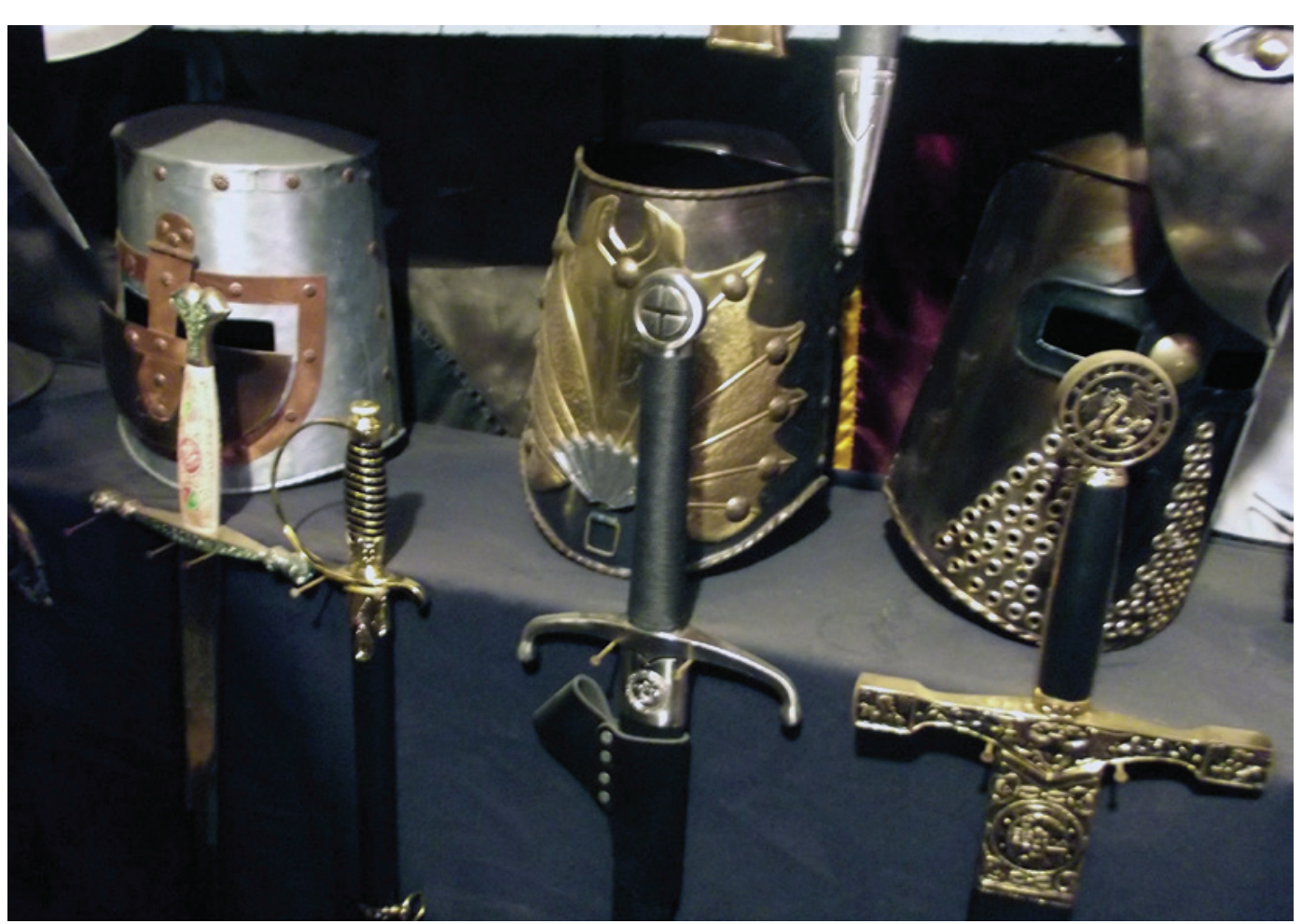

Figure 6: Output research and documentation: Julio González (medieval armour)

Seta's Pastori di Orgosolo (Bandits of Orgosolo, 1958) for the careful description of the different stages of a craft process and Jean Rouch's Jaguar (1967) for its use of narration. The shooting plan was explained to Julio and he was asked if it would be possible to start filming at the end of August. Unfortunately, we learnt at this point that Julio was experiencing a complicated situation with his health, having just been diagnosed with cancer, and needed to undergo an imminent operation. This news had a considerable emotional effect on the students and the class decided together that they would look for another subject for the documentary. Julio insisted, however, that he still wished to participate in the film despite the circumstances and expected to be able to do so by the end of September. Here, a key factor informing our planning was that the premiere of the short film was to take place at the cinema in Chile's Cineteca Nacional, along with offerings by other schools participating in the same programme, and this unfortunately made it difficult for us to modify the dates scheduled for filming. We resumed contact with Julio in late September. He, while insisting again he wished to participate in the documentary, requested the deadline be postponed further until the end of October, as he had had to undergo a further operation and felt very weak. Our students were very moved and each member of the class decided to write a letter to Julio González, thanking him for the motivation he had expressed and conveying their best wishes for his speedy recovery. One of the letters sent by the group read:

Dear Mr Julio, I'm sorry I can't meet you personally and what a shame for your cancer problem. I love your armour that I saw in the photos. I think that, because of the achievements you have made, working hard, you must continue to live forever.

After receiving these letters and amid an atmosphere of uncertainty for the students, Julio González replied in late October that he was very grateful for the students' words and that he would participate in the film 'against all odds'. 
In the weeks prior to this exchange of letters, the students had performed an exercise called 'Exploratory Shots' to help them consider how they would approach the place and theme of the documentary, while also providing progressive aspects of learning as to how sequences are constructed in documentaries and the training required for group filming. Three sequences documenting other crafts were made within the Patio La Rosa (the same space in which Julio's workshop was based), following a gardener, a welder and a toy carpenter (see Figure 7). In these sequences, certain aspects of filmmaking we had previously examined in class, now relevant to the documentary the students were planning, were practised, including depth field and interposed elements. In order to support their emerging practical work students analysed selected fragments of films, grouped into categories, allowing them to become aware of and make comparisons between the creative gestures of different filmmakers. Rather than focused on notions of film grammar, these categories were organized in order to assist students in developing their sensitivities to fundamental aspects of filmmaking such as the intervals between character and camera, the value of faces, changes over time within a shot and the establishment of visual parameters (depth field). The analysis of these fragments then encouraged students to shape their own proposals using the same categories during the making of their short films.

Navigating further difficulties, filming finally took place in the last few days of October. Julio González showed students how a medieval helmet is made, from the metal plate to the final rivets. The students worked one morning and two afternoons in rotating groups, accompanied by the facilitators of the course. They took a notebook with them on filming days, in which was written the script for the film and a description of the main shots. They had imagined a documentary with a clearly defined set of artistic objectives, but that nonetheless remained open to the opportunities presented on the ground when filming was taking place. In this respect, during filming students

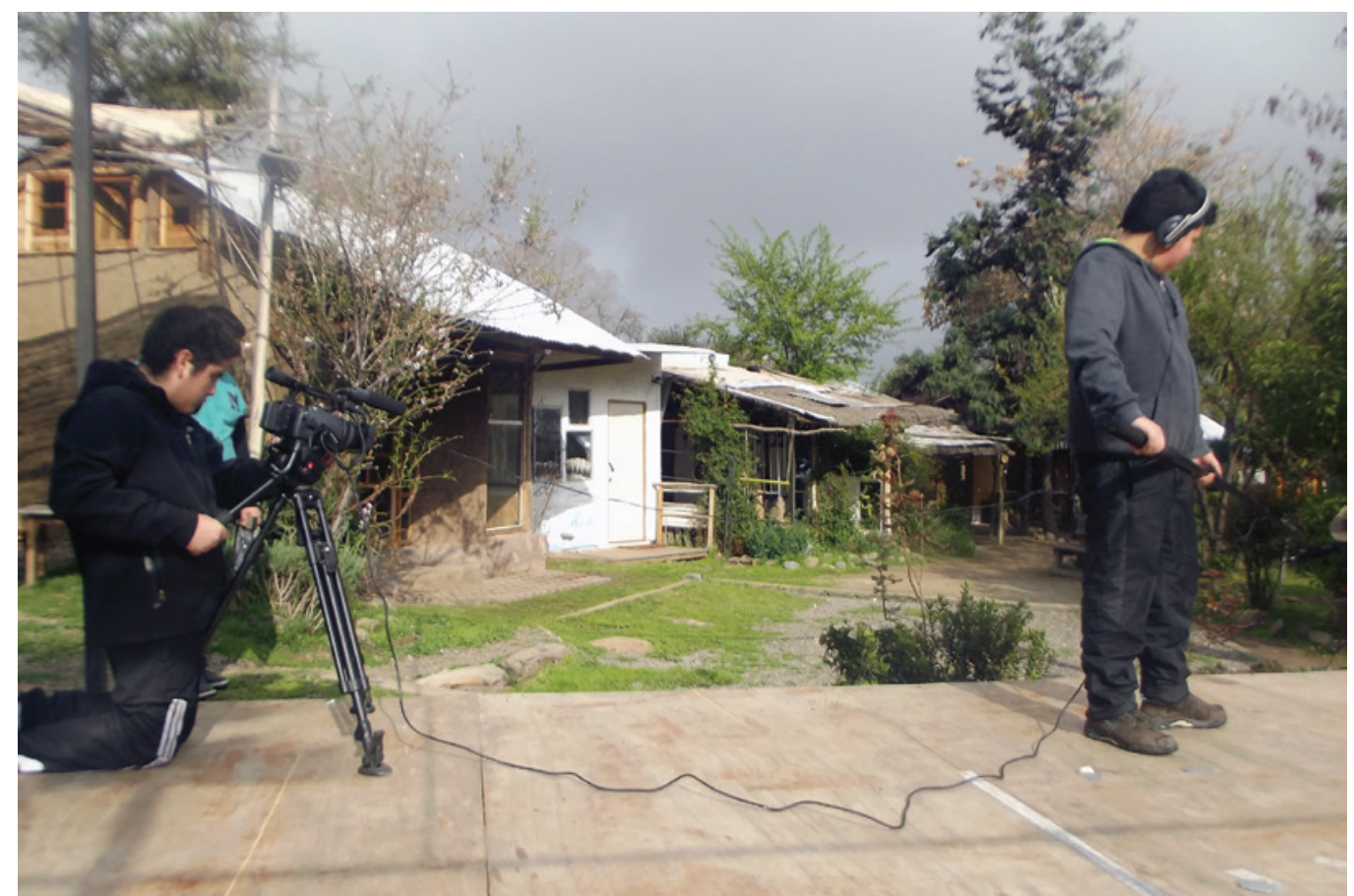

Figure 7: Exploratory shots in Patio La Rosa: Gardening

Source: Colegio Alicura 
had to learn to be patient, given the sometimes considerable length of time required for the construction of each shot.

Here, it seemed to us that the empathy that the students felt for the health complications that Julio González had experienced was a key element in fostering the team's attention and concentration during the shoot. The students carefully observed all the steps necessary to finalize a piece of armour, while deciding where to locate the camera in order to achieve a compelling framing, where to set the camera focus and so forth. Throughout the shoot myself (the filmmaker) and Marcela (the class teacher) were present to help students become aware of individual and group decision-making processes. Despite the increased attention arising from their respect and empathy for Julio we found that there were still moments in which we had to encourage the students to maintain their patience and concentration.

After filming was completed, the process of editing began. The entire class reviewed and analysed all the material that had been shot together, before each of the three film groups went on to edit the sequence they themselves had shot. Even from our early discussions and conception of the documentary, we had considered together the question of how the voice of the film's protagonist should be incorporated in the film. While, in the shots filmed by the class, Julio González was seen working in his workshop in silence, the class expressed the need also to convey aspects of his story with words. It was proposed they read a text Julio had sent to the group several weeks previously, to provide a 'voiceover' in the film. This was taken from a letter that had deeply impacted the class, entitled 'The Little Story', in which Julio chronicled events in his life. The title of the film was accordingly taken from this letter: La pequeña historia de un lobo de metal (The Little Story of a Metal Wolf) (see Figures 8a and 8b).

During the process of editing the documentary, which lasted three full days across two weeks, students were able to gain a full understanding of this process, from viewing all the filmed material. It is perhaps here that the students seemed to understand most clearly the artistic dimensions of the work they had developed. They started to develop a sense of the value of a given shot, both on its own terms and in relation to the film as a whole. While students initially felt all the takes shot were important and deserved to be in the movie, the editing process required them to discard material. For example, at one point during the edit, one of the students, after realizing his classmates had discarded from the initial sequence a pan shot he had directed, demanded that they put it back, defending with passion his conviction that the shot was central to the quality of the documentary as a whole.

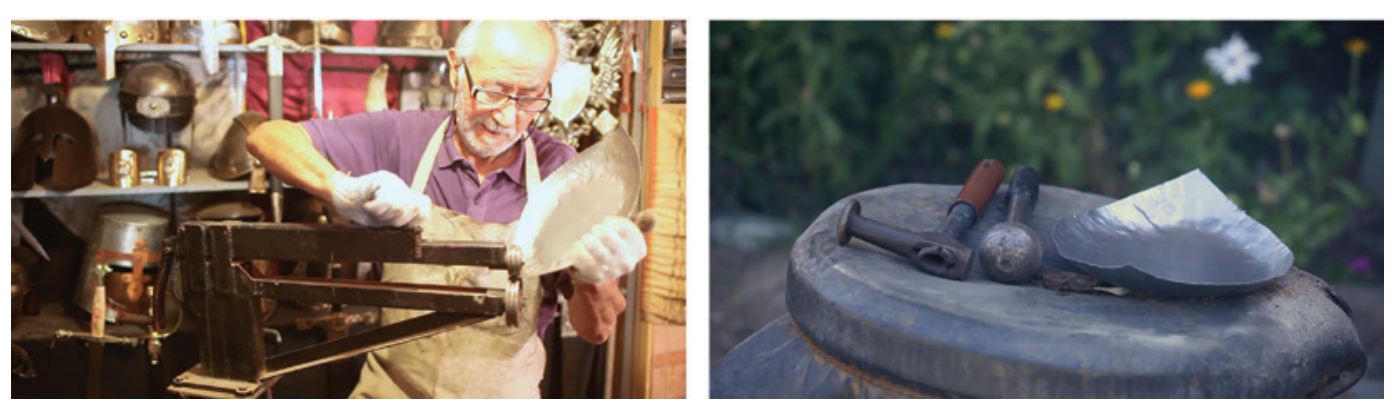

Figures 8a and 8b: Still frames of the documentary The Little Story of a Metal Wolf

Source: Colegio Alicura 


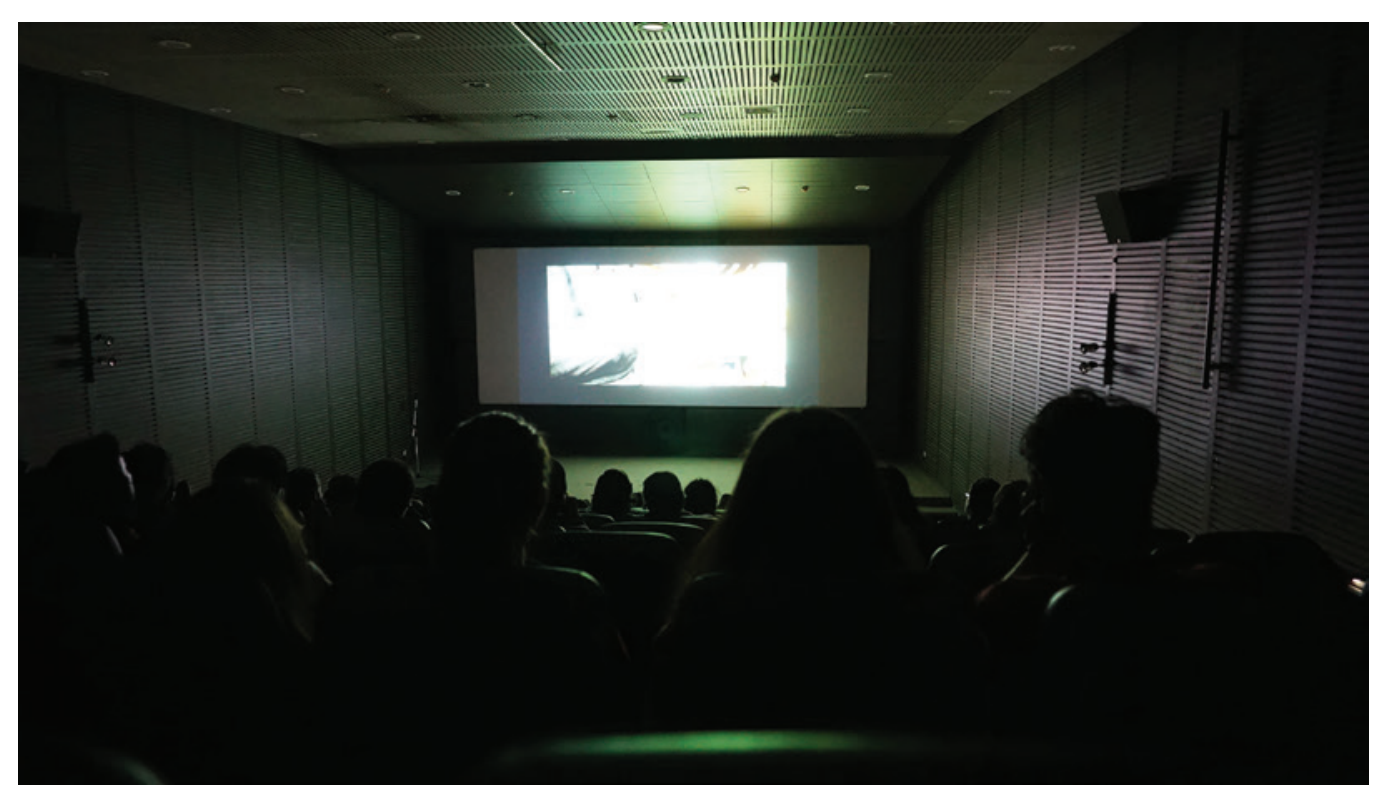

Figure 9: Premiere in the movie theatre of Cineteca Nacional de Chile with the participating schools in the programme Cine en curso Chile. After the screening of the documentary, the Colegio Alicura school group read the text about their creative process and then the public asked questions and made comments (for the full movie and the presentation by Colegio Alicura, see: https://vimeo. com/115092532 and https://vimeo.com/116494575)

The film finally received its premiere on 11 December (see Figure 9), attended by all six schools (Manuel de Salas School, Rudolf Steiner School, Cornelia Olivares School, Saint George College, República de Haití School and Alicura School) that had participated in Cine en curso Chile 2014. The schools made for a distinctly heterogeneous group in terms of socioeconomic factors, their respective locations within the region and their approaches to pedagogy. After the screening of films, each school read a text, prepared in class, about the creative process underlying the work. Within the methodology of Cinema en curs this text is key, allowing for the integration of learning, critical analysis and an overall synthesis of the project process carried out. After the screening of each film, the students who had made it answered the audience's questions, sharing their experiences, points of view and learning. When their turn came, the students from Alicura provided an exhaustive review of all the work of the year in which they thanked Julio González.

The preparation for the premiere helped students understand the whole process of making a film and its relationship with the final product or, in the words of Alain Bergala (2016: 36), to understand the film 'as the final trace of a creative process'. In this way, the learning and the subjective value of the moments lived were expressed in this text, through an assessment of the students' experience. Here we were able to see evidence that the students recognized that their teachers had believed in them, and that the latter had accompanied and supported them despite the difficulties, alongside their own effort and dedication in engaging with Julio González and the opportunity to learn about cinema and (with patience and perseverance) make a film.

\section{Conclusions}

In the final written assessment of their experience of Cine en curso Chile, the students who had participated in the project at Alicura School reported that they now felt 
themselves to be real filmmakers, able to analyse documentary films 'as professionals', as well as aspects of their own reality with a critical, aesthetic sense. At the beginning of the project, students seemed to have found it difficult to maintain attention or to contain feelings of frustration and anger arising from a process that did not meet their initial expectations. The previous experiences of cinema the students had had before participating in Cine en curso Chile had mainly consisted of watching commercial films rather than analysing documentaries about villages, neighbourhoods, workers and craftsmen and women. At several points, certain students even attempted to leave the course. The patience, care, participation and critical analysis the class went on to achieve by the end of the project is therefore all the more notable, and arguably was enabled in particular by the sense of accomplishment they were able to gain from each stage of the project, which seemed to have the effect of changing the disposition of the group and their level of motivation. Likewise, the practical exercises performed in advance of their final film shoot related students' developing experiences of cinema to an exploration of their daily lives using cameras and sound equipment, and this too seemed to generate in students a higher level of commitment to their work and a greater sense of responsibility.

In my opinion, it is rarely possible to know what specifically stays with students from their experiences of an art education project such as Cine en curso Chile, beyond what can be gleaned from assessments and evaluations. At the point of writing I remain unaware as to whether any of the students who participated in the project were able to generate a lasting relation with a film or, perhaps, might simply remember the composition of a shot that took a particularly long time to prepare or a special afternoon light in the schoolyard. If so, such aspects of learning would seem a great achievement, both for the students and for the project. Nonetheless, in sharing their work with other schools in a movie theatre at the end of the year the students seemed to feel 'a new sense of importance and a change to their self-concept. They realized that they could go beyond the ceiling that had been set for them both by the system they were a part of and by them themselves', as teacher Zegarra later commented. Through their experience with Cine en curso Chile, the class seemed able not only to critically examine and explore their reality, but also to share it in discovering, valuing and representing beauty that their peers and they themselves had not previously noticed in their surrounding environment. Finally, it is remarkable that the students stated that what struck them most about Julio González was his words, his strength and the passion he demonstrated to his craft. It could perhaps thus be stated, in the terms of the philosopher Byung-Chul Han (2015), that during their time with Cine en curso Chile, students at Alicura had an experience of beauty, as an experience of a commitment.

\title{
Notes on the contributor
}

Felipe Correa has a master's in visual anthropology from the University of Barcelona and teaches visual arts pedagogy at the Alberto Hurtado University in Chile. He has developed several publicly funded film education projects with Gaticine - Centro de desarrollo social del cine, in collaboration with organizations such as Cineteca Nacional de Chile and A Bao A Qu.

\section{Filmography}

\author{
De platte jungle (NL 1979, Johan Van der Keuken) \\ En Construcción (ES 2001, José Luis Guerín) \\ Jaguar (FR 1967, Jean Rouch)
}


La Matelassière (FR 1989, Alain Cavalier)

La pequeña historia de un lobo de metal (The Little Story of a Metal Wolf; CL 2015, Colegio Alicura) https://vimeo.com/115092532

Pastori di Orgosolo (IT 1958, Vittorio de Seta)

Planos exploratorios (CL 2014, Colegio Alicura) - https://vimeo.com/106292154

\section{References}

Aidelman, N. and Colell, L. (2014) 'Elogio del amor: Cine en curso'. Cinema Comparat/ ive Cinema, 2 (5), 24-30. Online. www.raco.cat/index.php/Comparativecinema/article/ download/288562/410994/ (accessed 11 August 2020).

Bergala, A. (2016) The Cinema Hypothesis: Teaching cinema in the classroom and beyond (FilmmuseumSynemaPublikationen 28). Trans. Whittle, M. Vienna: Austrian Film Museum.

Blandy, D. and Hoffman, E. (1993) 'Toward an art education of place'. Studies in Art Education, 35 (1), 22-33.

Byung-Chul Han (2015) La salvación de lo bello. Barcelona: Herder.

Colegio Alicura (2018) 'Proyecto educativo institucional'. Mineduc. Online. wwwfs.mineduc. cl/Archivos/infoescuelas/documentos/25247/ProyectoEducativo25247.pdf (accessed 3 November 2019).

Corte, F. and Concha, M. (2016) 'Estudio de caracterización de los programas de reinserción educativa de Sename y Mineduc'. Online. www.sename.cl/web/wp-content/uploads/2016/10/ Estudio_Caract_Prog_Reins_Sename-Mineduc.pdf (accessed 3 November 2019).

Eisner, E. (2018) Educar la visión artística. Barcelona: Paidós.

Mergendoller, J. and Thomas, J. (2005) 'Managing project-based learning: Principles from the field'. Buck Institute for Education (BIE). Online. http://citeseerx.ist.psu.edu/viewdoc/ download?doi=10.1.1.532.3730\&rep=rep1\&type=pdf (accessed 3 November 2019).

Unesco (2018) 'Textos fundamentales de la Convención para la salvaguardia del patrimonio cultural inmaterial de 2003'. Online. https://ich.unesco.org/doc/src/2003_Convention_Basic_ Texts-_2018_version-SP.pdf (accessed 3 November 2019).

Vega, A. (2018) Taller de cine para niños. Santiago: OchoLibros. 